ББК 26.34

\title{
INNOVATIVE APPLICATION \\ OF SOME COORDINATION COMPOUNDS OF ARSENIC AND STIBIUM
}

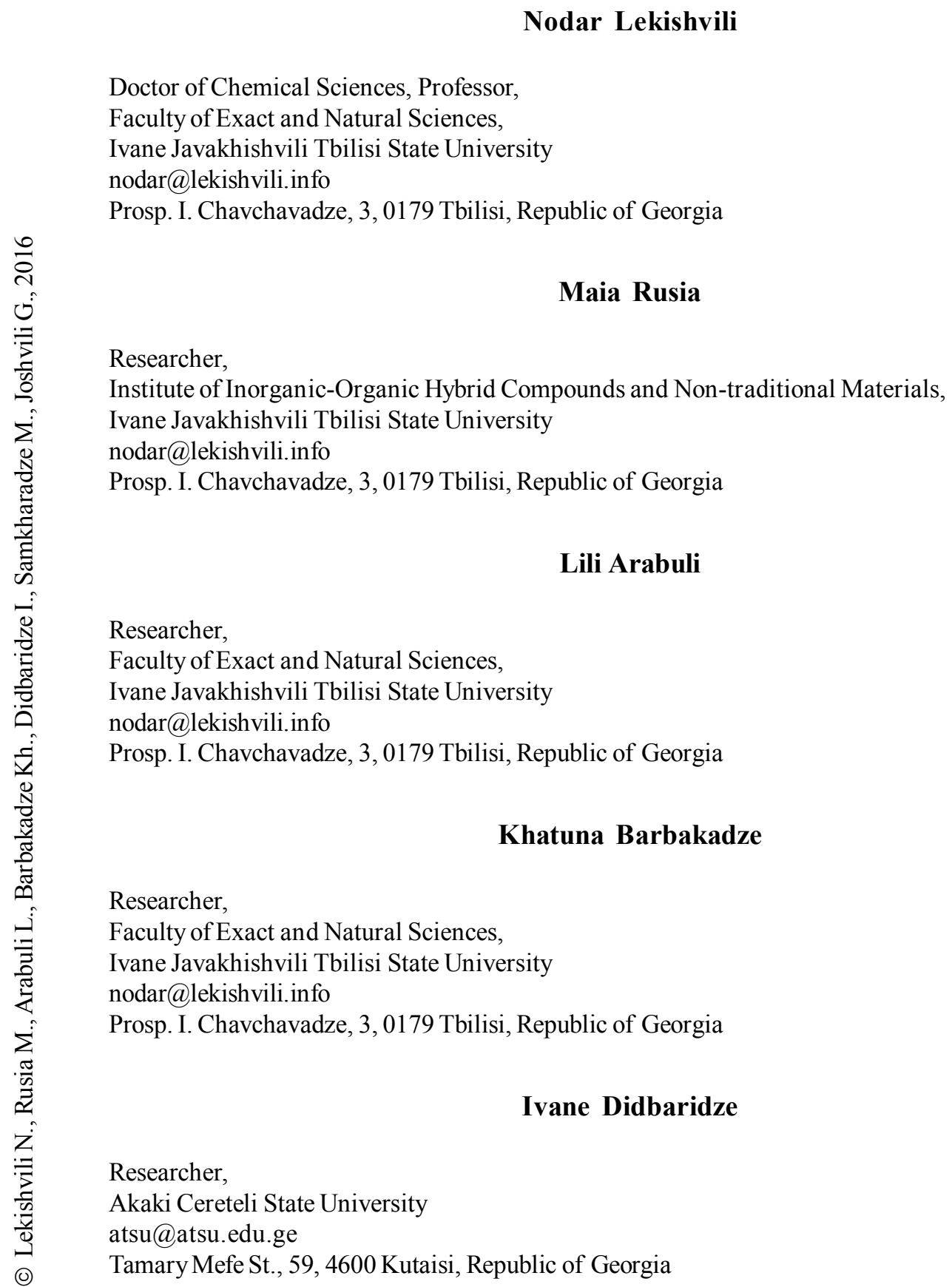

Maia Rusia

Researcher,

Institute of Inorganic-Organic Hybrid Compounds and Non-traditional Materials, Ivane Javakhishvili Tbilisi State University nodar@lekishvili.info

Prosp. I. Chavchavadze, 3, 0179 Tbilisi, Republic of Georgia

\section{Lili Arabuli}

Researcher,

Faculty of Exact and Natural Sciences,

Ivane Javakhishvili Tbilisi State University

nodar@lekishvili.info

Prosp. I. Chavchavadze, 3, 0179 Tbilisi, Republic of Georgia

\section{Khatuna Barbakadze}

Researcher,

Faculty of Exact and Natural Sciences,

Ivane Javakhishvili Tbilisi State University

nodar@lekishvili.info

Prosp. I. Chavchavadze, 3, 0179 Tbilisi, Republic of Georgia

\section{Ivane Didbaridze}

Researcher,

Akaki Cereteli State University

atsu@atsu.edu.ge

Tamary Mefe St., 59, 4600 Kutaisi, Republic of Georgia 


\title{
Madona Samkharadze
}

Researcher,

Akaki Cereteli State University

atsu@atsu.edu.ge

Tamary Mefe St., 59, 4600 Kutaisi, Republic of Georgia

\section{Giorgi Joshvili}

\author{
Researcher, \\ Faculty of Exact and Natural Sciences, \\ Ivane Javakhishvili Tbilisi State University \\ nodar@lekishvili.info \\ Prosp. I. Chavchavadze, 3, 0179 Tbilisi, Republic of Georgia
}

\begin{abstract}
Based on arsenic compounds obtained by transformation of arsenic industrial waste and natural resources (arsenic (III) oxide, arsenic (III) chlorides, alkoxides, stibium (III) oxide), we obtained and studied new coordination compounds, "white arsenic", hyperpure metallic arsenic and various materials with specific properties.

By using obtained non-volatile inorganic-organic complexes we created and tested new cheap anti-microbe substances and fungicides for protection of archaelogical items and museum exhibits and biological stuff. Based on the organic hetero-chain polymers modified by carbofunctional siliconorganic oligomers we created anti-biocorrosive covers for woodwork, goods from plastics and leather. We discussed the possibility of obtaining siloxane-arsenic oligomeric additions for under-water hydrophobic bioactive dye composites. We have shown the real perspective to manufacture madications, anti-helmintes, semi-conductors, optical glass-fibers and bio-medical nano composites based on Georgian region arsenic industrial waste and natural resources.
\end{abstract}

Key words: arsenic, stibium, chemical compounds, coordinations, inorganic-organic complexes, biomedical nanotechnologies.

\section{Introduction}

The problem of creation of a system of guarantee human and environmental protection from microorganisms attack for increasing of the human life quality has to be solved by:

- production of new effective medications;

- prevention of materials from biodeterioration and non-controlled biodegradation;

- inhibition of growth and expansion of microorganisms, which are causal factors of infectious - inflammatory sickness of human;

- prophylaxis and treatment of human diseases, provoked by microorganisms, crop's protection against diseases, caused by some microorganisms, and human protection during contact with them;

- obtaining biologically active compounds and composites with the aim of their inclusion into polymer matrix, using different methods of their fixation in the latter;

- study of biological activity of synthesized compounds and screening biologically active compounds $\mathrm{BAC}$ of natural derivation in relation to test-cultures of various microorganism genera biodestructors of polymer materials, etiological factors of the mycosis, plant pathogenes: Aspergillus, Penicillium, Cladosporium, Candida, Fusarium, etc.; - creation of polymer matrices by structurechemical modification of industrial polymers.

The perspective sources for obtaining various bioactive compounds are Georgian natural recourses.

Three main tendencies are well-defined while using production waste of Georgian chemical plants:

1. Regeneration of valuable compounds having noteworthy functions, from production waste $[6 ; 15]$. 
2. Recycling of so-called thrown-out and unused accumulated production waste and elaboration of technology of production of various useful cheap compounds from them [8].

3. Use of production waste for production of various compounds and materials having peculiar properties $[7 ; 8]$.

Arsenic is among the relatively less widespread elements [9]. Its deposits are located at the Georgian region, in general, as arsenic industrial waste and realgar-auripigment and arsenic pyrite $\left(\mathrm{As}_{2} \mathrm{~S}_{2}-\mathrm{As}_{2} \mathrm{~S}_{3}-\mathrm{FeAsS}\right)$ natural sourses. Pyrite, antimonite, nickel, gallium, manganese, titanium, copper etc. which are considered as second-rate mineral sources of arsenic which also contain it in small amounts.

One of the predominant raw materials of arsenic, realgar $\left(\mathrm{As}_{4} \mathrm{~S}_{4}\right)$ - auripigment $\left(\mathrm{As}_{4} \mathrm{~S}_{6}\right)$ ore is the world's only and unique. Dominant's content in this ore is especially high and reaches $10-12 \%$ [9]. Besides, it is very important that this ore doesn't contain admixtures of other elements and has bright prospects of receipt of not only metallic arsenic and $\mathrm{As}_{2} \mathrm{O}_{3}$ of high purity, but also other interesting products (Fig. 1) [11]. Despite of the fact that for extraction of arsenic and its products from realgar $\left(\mathrm{As}_{4} \mathrm{~S}_{4}\right)-$ auripigment $\left(\mathrm{As}_{4} \mathrm{~S}_{6}\right)$ ore first of all it is necessary to burn concentrate in special furnace, so environment pollution with sulfur dioxide and aerosol containing 2-3\% of white arsenic cannot be eliminated [2], that in case of revival of corresponding enterprise makes topical a manufacturing and putting into operation the catching devices with appropriate design.

Arsenic is also the natural associated element of a variety of nonferrous and noble metals after pyrometallurgical processing of arsenic ore that is one of the indispensable conditions of recovery of individual conditions of these metals. Industrial waste due to current technological processes contain arsenic in good supply (8-60\%) [22]. At the same time, they contain commercially significant amount of noble metals. In order to get rid of environmental pollution the residues are buried in special ground disposals, that is associated with considerable material and financial expenses.

During production of chemically pure arsenic sulfide from realgar-auripigment ore using vacuum-thermal method [14] along with desired product are originated coproducts, which contain desired product in significant amounts. Despite of the abovementioned, neither the technology of extraction of arsenic, and its satellite elements (e. g. stibium) from realgar-auripigment ore processing products, nor application areas for products received from waste are not assimilated to the full extent today and require further development from the viewpoint of creation of cheap raw materials base on their basis.

In the represented article we consider production waste of former mining and chemical plants of Georgian arsenic production as secondary resources for receipt of important arsenic-containing compounds.

\section{Georgian regional natural secondary recources of arsenic industry}

There are considerable reserves in Georgia for extraction of arsenic in its various forms (e. g. sulfides, oxides) from arsenic production waste (arsenic pyrite and realgar-auripigment processing waste and waste of pyrometallurgical production) and for production of relatively cheap important compounds and materials with peculiar properties, for example, pharmaceutical preparations, anthelminthics, antimicrobial and parasiticide compounds, conserving agents, as well as industrial-use (for technical purposes) and bioactive synthetic compositions and materials [4, 15-17]. There is a real prospect of production of arsenic-containing nontraditional
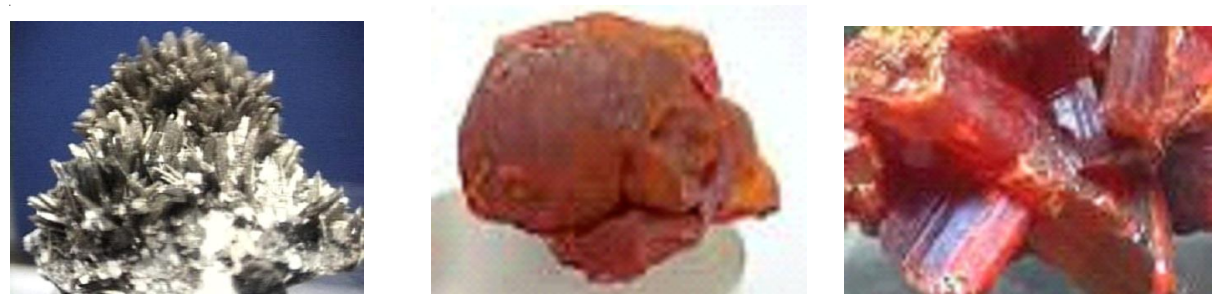

Fig. 1. The samples of arsenopirit $(a)$, realgar $(b)$ and auripigment $(c)$ 
advanced materials, antibiocorrosive coatings, nanocomposites and nanomaterials of biomedicine and microelectronic purposes on the basis of arsenic production waste [18; 19].

We have established that arsenic-containing production waste may be used as starting material for production of gold, barium hydrous arsenate, strontium hydrous arsenate, magnum-ammonium arsenate, sodium monoselenoarsenate, cyclic esters of arsenic acid etc. Among them barium hydrous arsenate is the best anthelmintic. Strontium hydrous arsenate is used in homeopathy, while in veterinary it is used as anthelmintic. Magnum-ammonium arsenate is used in production of special-purpose glasses, sodium monoselenoarsenate - as insecticide, while cyclic esters of arsenic acid are used for production of insecticides, as inhibitors of lubricants' oxidation, as antioxidant for synthetic rubber, for production of some copolymers, etc.

Homeopathy [20], as one of the most interesting directions of therapy has attracted a serious attention in the last years, in which the possibilities of application of some arsenic compounds received on the basis of production waste seem to be very prospective.

Development of abovementioned directions will promote creation of cheap raw materials base that will make accessible the production of well-known and new arsenic-containing compounds having a lot of interesting properties and will simplify their practical implementation (Fig. 2).

Esters of arsenic acids received from production waste may be used for production of a variety of new arsenic-containing preparations, which have found manifold uses. First of all the most important is the possibility of gold extraction from pyrometallurgical waste, as well as receipt of barium hydrous arsenate, strontium hydrous arsenate (used in medicine, namely, in homeopathy, while in veterinary - as anthelmintic), sodium mono-selen-arsenate, cyclic esters of arsenic acid and other substances. Magnumammonium arsenate (V) is widely used in production of special-purpose glasses. Demand for this preparation increases day by day in the last years. That's why elaboration of upgraded method of its production [1] is of great practical importance.

Table 1 presents the structure of some important inorganic and organic arsenic compounds.

In market conditions it can be used as intermediate product. Namely, products of interaction of this compounds and monoatomic spirits of saturated row ( $\mathrm{ROH}$, where $\mathrm{R}=\mathrm{C}_{5} \mathrm{H}_{11}$ or iso- $\mathrm{C}_{5} \mathrm{H}_{11}$ ) during chemical reactions manifest such behavior as if we have arsenic oxide (III) of high purity. As we already have mentioned above, interaction of spirits and white arsenic, including arsenic anhydride contained in mixtures, represents well-defined selective reaction, as a result of which the ester of arsenic acid of high condition is received. The latter in its turn, as all compound esters, easily experience hydrolyzation in water solutions, with formation of white arsenic and corresponding spirit. Arsenic oxide (IV) manifests the same properties. This circumstance can be successfully used not only for production

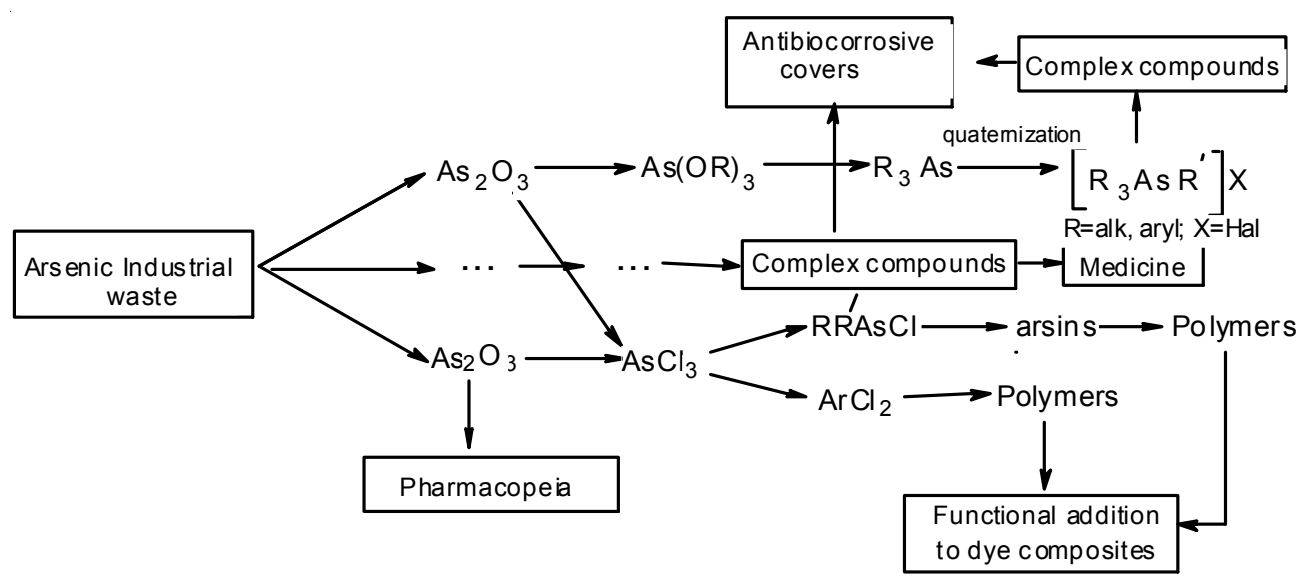

Fig. 2. The scheme of obtaining and using some important arsenic- and stibium-containing compounds from arsenic industrial waste 
Basic physical-chemical properties of coordination compounds of some Tertiary Arsines with Mercury (II) Halides $\left(\mathrm{HgHal}_{2} \mathrm{As}(\mathrm{R}) \mathrm{Ar}_{2}\right)$

\begin{tabular}{|c|c|c|c|c|c|c|c|c|c|c|}
\hline \multirow[t]{2}{*}{ № } & \multirow[t]{2}{*}{ Ar } & \multirow[t]{2}{*}{$\mathrm{R}$} & \multirow[t]{2}{*}{$\mathrm{Hlg}$} & \multirow{2}{*}{$\begin{array}{c}\text { Melting } \\
\text { Poin, } \\
\text { t, }{ }^{\circ} \mathrm{C}\end{array}$} & \multirow{2}{*}{$\begin{array}{c}\text { Molar Electric } \\
\text { Conductivity } \\
\text { in dimethylfor- } \\
\text { mamid } \\
\text { at } 25{ }^{\circ} \mathrm{C} \\
\mathrm{om}^{-1} \mathrm{~cm}^{2} \mathrm{~mol}^{-1}\end{array}$} & \multicolumn{2}{|c|}{ Found, \% } & \multirow{2}{*}{$\begin{array}{l}\text { Brutto } \\
\text { formula }\end{array}$} & \multicolumn{2}{|c|}{ Calculated, \% } \\
\hline & & & & & & As & $\mathrm{Hlg}$ & & As & $\mathrm{Hlg}$ \\
\hline 1 & $m-\mathrm{CH}_{3} \mathrm{C}_{6} \mathrm{H}_{4}$ & $m-\mathrm{CH}_{3} \mathrm{C}_{6} \mathrm{H}_{4}$ & $\mathrm{Cl}$ & $173-174$ & 24.6 & 11.70 & 11.52 & $\mathrm{C}_{21} \mathrm{H}_{21} \mathrm{AsHgCl}_{2}$ & 12.09 & 11.45 \\
\hline 2 & $m-\mathrm{CH}_{3} \mathrm{C}_{6} \mathrm{H}_{4}$ & $\mathrm{C}_{2} \mathrm{H}_{5}$ & $\mathrm{Cl}$ & $137-139$ & 25.7 & 13.15 & 13.64 & $\mathrm{C}_{16} \mathrm{H}_{19} \mathrm{AsHgCl}_{2}$ & 13.44 & 12.72 \\
\hline 3 & $m-\mathrm{CH}_{3} \mathrm{C}_{6} \mathrm{H}_{4}$ & iso- $\mathrm{C}_{4} \mathrm{H}_{9}$ & $\mathrm{Cl}$ & $143-144$ & 25.4 & 12.45 & 12.02 & $\mathrm{C}_{18} \mathrm{H}_{23} \mathrm{AsHgCl}_{2}$ & 12.79 & 12.12 \\
\hline 4 & $\mathrm{C}_{6} \mathrm{H}_{5}$ & $n-\mathrm{C}_{4} \mathrm{H}_{9}$ & $\mathrm{Cl}$ & $122-123$ & 23.1 & 13.40 & 12.72 & $\mathrm{C}_{16} \mathrm{H}_{19} \mathrm{AsHgCl}_{2}$ & 13.44 & 12.72 \\
\hline 5 & $\mathrm{C}_{6} \mathrm{H}_{5}$ & iso $-\mathrm{C}_{3} \mathrm{H}_{7}$ & $\mathrm{Cl}$ & $150-151$ & 28.4 & 13.28 & 13.10 & $\mathrm{C}_{15} \mathrm{H}_{17} \mathrm{AsHgCl}_{2}$ & 13.79 & 13.05 \\
\hline 6 & $\mathrm{C}_{6} \mathrm{H}_{5}$ & $\mathrm{C}_{6} \mathrm{H}_{5}$ & $\mathrm{Br}$ & $180-181$ & 22.6 & 11.17 & 23.89 & $\mathrm{C}_{18} \mathrm{H}_{15} \mathrm{AsHgBr}_{2}$ & 11.24 & 23.99 \\
\hline 7 & $m-\mathrm{CH}_{3} \mathrm{C}_{6} \mathrm{H}_{4}$ & $m-\mathrm{CH}_{3} \mathrm{C}_{6} \mathrm{H}_{4}$ & $\mathrm{Br}$ & $164-165$ & 25.4 & 10.20 & 22.33 & $\mathrm{C}_{21} \mathrm{H}_{21} \mathrm{As}_{2} \mathrm{HgBr}_{2}$ & 10.57 & 22.57 \\
\hline 8 & $m-\mathrm{CH}_{3} \mathrm{C}_{6} \mathrm{H}_{4}$ & $\mathrm{C}_{2} \mathrm{H}_{5}$ & $\mathrm{BrBr}$ & 131-139 & 27.7 & 11.49 & 24.72 & $\mathrm{C}_{16} \mathrm{H}_{19} \mathrm{AsHgBr}_{2}$ & 11.59 & 24.73 \\
\hline 9 & $\mathrm{C}_{6} \mathrm{H}_{5}$ & $n-\mathrm{C}_{4} \mathrm{H}_{9}$ & $\mathrm{Br}$ & $147-148$ & 22.4 & 11.32 & 24.66 & $\mathrm{C}_{16} \mathrm{H}_{19} \mathrm{AsHgBr}_{2}$ & 11.59 & 24.73 \\
\hline 10 & $m-\mathrm{CH}_{3} \mathrm{C}_{6} \mathrm{H}_{4}$ & iso- $\mathrm{C}_{4} \mathrm{H}_{9}$ & $\mathrm{Br}$ & $145-148$ & 26.9 & 11.09 & 23.42 & $\mathrm{C}_{18} \mathrm{H}_{23} \mathrm{AsHgBr}_{2}$ & 11.11 & 23.70 \\
\hline 11 & $\mathrm{C}_{6} \mathrm{H}_{5}$ & iso- $\mathrm{C}_{3} \mathrm{H}_{7}$ & & $158-159$ & 29.5 & 11.36 & 24.98 & $\mathrm{C}_{15} \mathrm{H}_{17} \mathrm{AsHgBr}_{2}$ & 11.84 & 25.28 \\
\hline
\end{tabular}

of well-known and widely used compounds, but also for synthesis of novel compounds. Use of ester of arsenic acid as source raw material eliminates carrying out of such hazardous and complex processes as the receipt of high-toxicity arsenic compounds $\left(\mathrm{AsH}_{3}, \mathrm{AsCl}_{3}\right)$, their purification and reduction up to metallic arsenic or transformation into compounds with peculiar properties [22].

We established that there is no necessity for burying so-called "tails" of arsenic production in appropriate ground disposals, if there is no arsenic in form of oxide in them. They can be used as intermediate product. Namely it is possible to process them by monoatomic spirits $\mathrm{ROH}$ of saturated row, where $\mathrm{R}=\mathrm{C}_{4} \mathrm{H}_{9}, \mathrm{C}_{5} \mathrm{H}_{11}$, iso- $\mathrm{C}_{5} \mathrm{H}_{11}$ or by $\mathrm{C}_{6} \mathrm{H}_{13}$ using the method of azeotropic dehydration. This process is based on well-defined selective reaction, since among residues only arsenic oxides or corresponding acids undergo a reaction with spirits, while coproducts remain on the bottom of reactor in form of slugs. High purity esters of arsenic acids are received as a result of reaction. They as all compound esters are easily hydrolyzed in the water solutions with formation of white arsenic and corresponding spirit. Obtained spirit can be used again as extragent, so this process takes continuous character and at the same time, cyclical pattern. It is clear that there will be anyway a negligible loss of spirit that is consumed for soaking of spirit. Obtained spirit extracts can be successfully used once more for receipt of both inorganic and organic compounds.

Methods of receipt of very important arsenic compounds - arsenic oxides (e. g. "white arsenic"), arsenic sulfides, metallic arsenic of high purity and other compounds on the basis of waste of hydro- and pyrometallurgical production are described in the literature $[4 ; 22-26]$. Mentioned compounds represent basic/starting substances for production of arsenic-containing compounds [27; 28].

Among arsenic products the receipt of one of the most valuable substances - metallic arsenic of high purity is of especial importance. This production is based on the preliminary treatment of some of arsenic-containing compound and afterwards on its chemical transformation [12]. Elaboration of intensive technology of metallic arsenic production is one of the most topical problems of arsenic chemistry and technology, all the more if we use production waste transformation products as starting substances.

Use of ester of arsenic acid as source raw material eliminates carrying out of such hazardous and complex processes as are the receipt of hightoxicity compounds $\left(\mathrm{AsH}_{3}, \mathrm{AsCl}_{3}\right)$, their purification and reduction up to metallic arsenic or transformation into compounds with peculiar properties [22].

Thus, in abovementioned direction, chemistsresearchers and entrepreneurs pay a lot of 
attention to development of such progressive and economically substantiated technologies, where:

- amount of operations for receipt of ester of arsenic acid obtained from arsenic-contained waste is reduced to minimum that considerably simplifies the quality control of obtainable product;

- extraction of highly explosive (e. g. $\mathrm{H}_{2}$ ) and toxic coproducts (e. g. $\mathrm{HCl}$ etc.) have to be eliminated.

Use of compounds received in agriculture from arsenic-contained waste (mostly in the form of alkali salts $\left(\mathrm{Na}_{3} \mathrm{AsO}_{4}\right)$ ) in relation with escalation of fighting with environmental pollution decreases more and more, while areas of metallic arsenic application are extended. Namely it is used in up-to-date technologies [28; 29], while $\mathrm{Ga}_{2} \mathrm{As}_{3}$ and InAs (arsenides) are used for manufacturing of luminescent and laser, microwave and switching diodes, detectors, transistors, solar batteries, integrated circuits and microelectronic devices.

Ultra-clean metallic arsenic is used in semiconductors production, as well as for manufacturing of various alloys [30].

Arsenic (III) extracted from production waste may be used as intermediate product for receipt of various compounds with reacting capacity. For example, products of interaction of this compounds and saturated monoatomic spirits $(\mathrm{R}>\mathrm{Bu})$ manifest such behavior in chemical reactions as arsenic oxides of high-quality of purity [31]. We established that interaction of spirits and white arsenic represents well-defined selective reaction as result of which is received the ester of arsenic acid of high condition. The latter in its turn as all compound esters easily experience hydrolyzation in water solutions, with formation of white arsenic and corresponding spirit. Obtained spirits can be used again as extragents. This means that process has continuous and at the same time cyclic nature. It is clear that there will be anyway a negligible loss of spirit that is consumed for soaking of solid phase. Obtained spirit extracts can be successfully used once more for receipt of both inorganic and organic compounds. As it turns out, products of transformation are considerably of high-quality than it is accomplished directly on the basis of "white arsenic". Abovementioned researches have been further developed during last 5-6 years that was reflected in numerous articles and abstracts of international reports.

Among arsenic-containing compounds the most interesting are tertiary arsines and their salts [31]. As it turns out from the review of corresponding scientific literature, tertiary arsines easily alkylate via "inclusion" into chemical bond of $4 \mathrm{~s}^{2}$-electrons of central atom, and form arsonium salts of polyfunctional composition. Organic iodine derivatives play the role of electrophile for the most part, since in contradistinction from other halogen derivatives they easily enter into reaction of nucleophilic addition.

Thus, arsonium salts with general formula $\left[\mathrm{R}_{4} \mathrm{As}\right] \mathrm{X}$, where $\mathrm{R}$ - organic radical (alkyl, alkylene or aromatic), while $\mathrm{X}=\mathrm{Hal}^{-}, \mathrm{NO}_{3}^{-}$, $\mathrm{CH}_{3} \mathrm{COO}^{-}$etc., should be considered as cationic complexes, since they experience electrolytic dissociation in water or other polar solvents according to the following equation:

$$
\left[\mathrm{R}_{4} \mathrm{As}\right] \rightleftarrows\left[\mathrm{R}_{4} \mathrm{As}\right]^{+}+\mathrm{X}^{-}
$$

It should be noted that there are no similar radicals among all 4R's. Moreover, the most difficult of receipt and, therefore, of study is the case when we deal with asymmetric arsonium halogenides. The latter substances are received by alkylation of tertiary arsines:

$$
\mathrm{R}_{3} \mathrm{As}+\mathrm{R}-\mathrm{Hal} \rightarrow\left[\mathrm{R}_{4} \mathrm{As}\right] \mathrm{Hal}
$$

Also noteworthy is the fact that tetraalkyl(aryl)arsonium salts represent the best precipitators for a variety of complex anions [10].

Receipt of cationic-anionic complexes of tetra-substituted arsenic (arsonium) is possible not only by exchange and addition reactions, but also by substitution reaction [4].

Proceeding from abovementioned and also with the use of arsenic chemical raw materials and other kinds of waste available in Georgia, from the practical viewpoint (biological activity) the coordination compounds on the basis of tertiary alkyl(aryl)arsines are very prospective [22; 23].

Impact of arsenic as of toxic element on flora and fauna of Racha and Svaneti (Georgia) is considerable that makes a recycling of accumulated waste of its production even more topical. 


\section{ТЕХНИКО-ТЕХНОЛОГИЧЕСКИЕ ИННОВАЦИИ}

At this moment, in abovementioned direction, chemists-researchers and entrepreneurs pay a lot of attention to development of such progressive and economically substantiated technologies, where:

- amount of operations for receipt of ester of arsenic acid obtained from arsenic-contained waste is reduced to minimum that considerably simplifies the quality control of obtainable product;

- extraction of highly explosive (e. g. $\mathrm{H}_{2}$ ) and toxic coproducts (e. g. $\mathrm{HCl}$ etc.) has to be eliminated;

- possibility of formation of toxic intermediate products or waste (which requires neutralization of burying) should be reduced to the minimum in the whole treatment cycle;

- environment should be protected from pollution and poisoning with high-toxic substances.

Processing and transformation of stibiumcontaining production waste into stable coordination compounds of peculiar properties is important with the purpose of its further use that ranges among topical problems of modern applied and coordination chemistry. Successful solution of this problem not only will create new raw materials base but also will solve important ecological problem - will protect environment from pollution with stibium-containing waste. Certain positive results are obtained by Georgian scientists-chemists in this direction, who carry out a synthesis and study a lot of interesting stibium compounds (Prof. R. Gigauri and colleagues).

There is the method of possible separation of arsenic (III) and stibium (III) oxides from each other [4]. Azeotrope effective for this process is selected.

The used method is based on the fact that arsenic oxide quantitatively completely interacts with spirits, e. g. with butyl spirit with formation of tributyl arsenite, and as a result of its hydrolysis is received white arsenic of high purity; arsenic and stibium oxides which are not included into reaction turn out to be constituent component of pyrometallurgical waste of many polyelement ores, that's why elaboration of low-temperature methods of their removal and separation from waste is interesting issue for production processes.

Abovementioned method is rather economically viable compared with other current methods.

Among stibium compounds, stibium (III) oxide and stibium (III) sulfide (Fig. 3) are also important from the practical viewpoint. Stibium (III) oxide is used for production of modern fireproof dyes and enamels, brand new functional materials and composites.

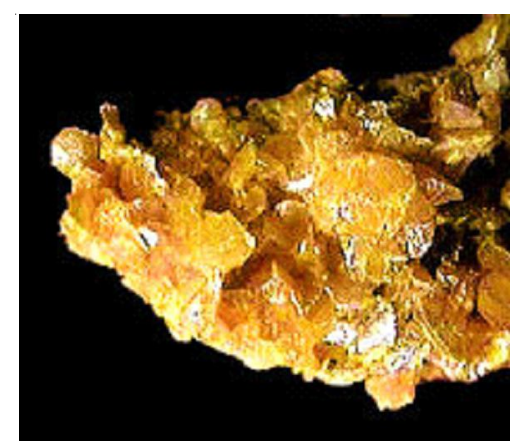

Fig. 3. The crystale of As(III) sulfide

Stibium (III) sulfide is used in match production, as well as in military industry. Stibium compounds are widely used in pharmaceutical, textile and other technologies. Stibium is also produced in Georgia in the form of sulfide minerals, which are known under the label of antimonites $\left(\mathrm{Sb}_{2} \mathrm{~S}_{3}\right)$. Content of basic metal in commercial brands of metal stibium, which are available at world market, reaches $99,95 \%$.

Among stibium (V) compounds one of the most important is sodium thiostibiate $\mathrm{Na}_{3} \mathrm{SbS}_{4}$, which is good complex-former [12-14]. Due to it, from the economic viewpoint, receipt of stibium compounds (as of arsenic satellite elements) on the basis of arsenic production waste is of especial importance, that will make cheaper corresponding final compounds and as a result, coordination compounds derived from them.

In the era of the violent technical progress, wide assortments of synthetic and natural polymeric materials have been produced. At the same time, there appeared various aggressive microorganisms (more than several hundred), which can destruct these materials, especially carbon-containing. Losses caused by this mean reach enormous amounts and constitute annually milliards of dollars.

Together with mentioned above, protection of historical buildings, archeological examples, museum exhibits and collections is global problem and this topic is urgent all over the world. Many congresses and symposiums are dedicated to this topic. Substantial funds are allocated for solving this problem. 


\section{ТЕХНИКО-ТЕХНОЛОГИЧЕСКИЕ ИННОВАЦИИ}

One of the ways to protect from aggressive microorganisms and fungi of wide range synthetic and natural materials is creation of direct action multi-functional synthetic antibiocorrosive coatings based on various inorganic-organic hybrid composites (Fig. 4).

We have developed new antibiocorrosive coatings $[19 ; 22]$ where as a bioactive components are used stable, non-volatile organo-metallic complexes, safety for human life in conditions of certain concentrations, also highly dispersed bioactive inorganic (possibly nano-particles) obtained by transformation of the secondary raw material. Bioactive compounds dropped into the polymeric carriers modified with industrial functional polymers, which are distinguished with good compatibility.

Obtained antibiocorrosive coatings:

- are characterized by a good fixation on various synthetic and natural materials, as well as on museum exhibits and archeological samples;

- they do not violate wholeness of samples during hardening of the cover composites;

- they are transparent (Fig. 5-6) and almost do not change the color during their aging;

- they have enough strength, elasticity and stable mechanical characteristics (they do not scratched easily and do not change relief of the surface) and high hydro-phobility $(<0.1 \%)$, typical for such materials;

- they are not dangerous for human; during long time of exploitation they do not produce harmful gases; they are relatively cheap and available.

Their thermal stability (in air, isothermal aging at $40{ }^{\circ} \mathrm{C}$ and $60{ }^{\circ} \mathrm{C}$ ), on action of so called "lightweather" (complex action of moisture and of air oxygen, of sun scattered ultraviolet radiation and $\mathrm{CO}_{2}$ ) showed, that during the long period the initial expression, color, optical transparency and mechanical properties (homogeneity of the surface without formation of splits) antibiocorrosive coatings did not worsen.

Instead of easily swillable tin- and arsenicorganic low molecular antibacterial additives to dyecomposition with specific properties were used industrial silicon polymer modified by bioactive fragment:

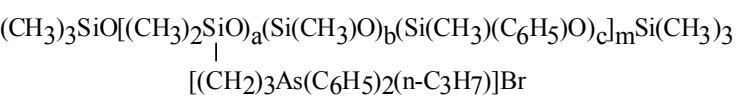

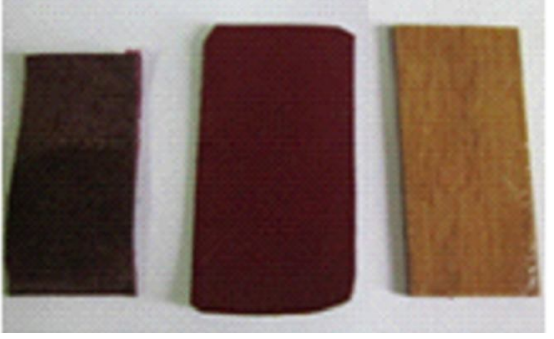

Fig. 4. Antibiocorrosive coatings containing inorganic-organic bioactive structures obtained by transformation of the arsenic industrial waste:

$I$ and $I I$ samples - leader, $I I I-$ wood

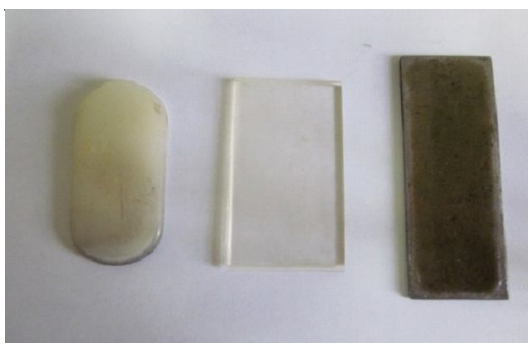

Fig. 5. Antibiocorrosive coatings

(first two samples) and due composite contained bioactive silicon polymer:

first sample from left - antibiocorrosive coatings for polycarbonate plate based on high dispersed stibium (III) oxide and polyepoxide modified by industrial silicon polymer; second sample from left - optically transparent antibiocorrosive coatings for organic glass plate based on high dispersed stibium (III) oxide and polyepoxide modified by siliconorganic oligomer; third sample from left - dye composite, contained bioactive silicon polymer for protection of under-water part of the ship

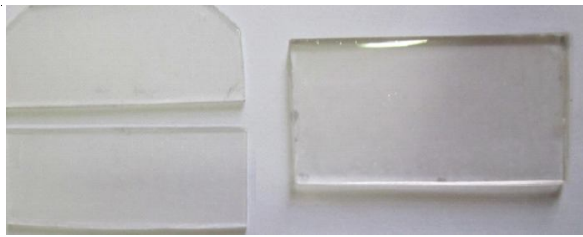

Fig. 6. Left column: first and second samples from the top - optically transparent antibocorrosive coatings based on high-disperssed stibium (III) oxide and copolymer of perfluoromethacrylate and ethylmethacrylate covered on the polycarbonate plate; right column: optically transparent antibocorrosive coatings based on high-disperssed stibium (III) oxide and copolymer

of perfluoromethacrylate and ethylmethacrylate covered on the organic glass plate

In case of necessity, it is possible to obtain anti-bio-corrosive coatings with different color 
(Fig. 4-5) what can be adjusted by selecting of appropriate bioactive components.

\section{The potential spheres of using obtained bioactive composites are:}

- prevention of materials from biodeterioration, non-controlled biodegradation various branches of industry and human protection during contact with this materials;

- inhibition of growth and expansion of microorganisms, which are causal factors of infection - inflammatory sickness of human and animals; for prophylaxis of above mentioned diseases, provoked by microorganisms;

- protection of museum exhibits and some of cultural heritage;

- for obtaining of dye-composition for protection of underwater part of the ship toward aggresive microorganisms excreted by some algae.

It must be noted that in case of need it will be possible to remove some of the antibiocorrosive covers from the surface without damaging it, which is especially important during the restoration of museum exhibits and archaeological samples.

According to the information obtained from scientific literature of last decade, the interest toward stibium and its traditional compounds seems to be reduced relatively worldwide. More attention is switched to arsenic and its compounds [27;28]. This fact can be caused by the circumstance that best efforts are focused on removal from environment and desired use of arsenic as one of the most undesirable pollutant, while stibium is easily removed from almost all satellite elements.

At present special attention is paid to synthesis and research of hybrid arsenic compounds having biocide properties, since some of them may be successfully used for receipt of bioactive additives, biostable polymers, dyes etc., and part of them is used against phytopathogenic bacteria. Based on this positions it is clear that synthesis of arsenic-containing compounds and study of their biocide properties are carried out intensively [9-11].

In the recent years the ministry of environment protection and natural resources of Georgia is vitally interested in solution of this problem. For this purpose a special six-year program named "Recycling and decontamination of production waste of arsenic mining and chemical plants of Georgia" has been elaborated by the ministry last year. This program is in full compliance with project represented by us. In case of winning of this project the focuses of environmental pollution with the waste obtained as a result of arsenic ore processing will be deactivated. Their harmful impact on human's health will be maximally decreased, and tourism development and production of ecologically clean agriculture product in the Georgian region (Svaneti and Racha) will be promoted.

\section{Novel bioactive hybrid coordination compounds of some tertiary arsines with mercury (II) halides}

We have synthesized [25] two types of coordination compounds: $\mathrm{Ar}_{2} \mathrm{AsR} \cdot \mathrm{HgCl}_{2}$ and $\mathrm{Ar}_{3} \mathrm{As} \cdot \mathrm{HgX}_{2}(\mathrm{X}=\mathrm{Cl}, \mathrm{Br})$ (Table 1$)$. Asymmetry tertiary arsines complexes type of $\mathrm{Ar}_{2} \mathrm{AsR} \cdot \mathrm{HgCl}_{2}$ (where Ar is aryl and R - alkyl) were formed according to the following reaction scheme:

$$
\mathrm{Ar}_{2} \mathrm{AsR}+\mathrm{HgCl}_{2} \rightarrow \mathrm{Ar}_{2}(\mathrm{As}) \mathrm{R} \cdot \mathrm{HgCl}_{2}
$$

It was shown that symmetric trialkyl arsines could not form crystalline compounds with mercury(II) chlorides:

$$
\mathrm{R}_{3} \mathrm{As}+\mathrm{HgCl}_{2} \text { 大 } \mathrm{R}_{3} \mathrm{As} \cdot \mathrm{HgCl}_{2} \text { ， }
$$

where $\mathrm{R}=n-\mathrm{C}_{3} \mathrm{H}_{7}$, iso $-\mathrm{C}_{5} \mathrm{H}_{11}$ or $\mathrm{C}_{7} \mathrm{H}_{25}$.

Symmetric triaryl arsines have formed with mercury (II) halides crystalline products:

$$
\mathrm{Ar}_{3} \mathrm{As}+\mathrm{HgX}_{2} \rightarrow \mathrm{Ar}_{3} \mathrm{As} \bullet \mathrm{HgX}_{2},
$$

where $\mathrm{Ar}=\mathrm{C}_{6} \mathrm{H}_{5}$ or $m-\mathrm{CH}_{3}-\mathrm{C}_{6} \mathrm{H}_{4}, \mathrm{X}=\mathrm{Cl}$ or $\mathrm{Br}$.

It was established that the change of the ratio of initial reagents (in wide limits) did not influence the chemical composition of the products - it was always equal to $1: 1$. The assumption that the obtained products are identical was confirmed by the fact that their melting point did not change. Thus based on numerous experiments optimal conditions for this process were elaborated. All synthesized products are white crystalline, stable compound. It was established that the yield in case of triarylarsines is far less than in case of diaryl(alkyl)arsines. The rate of formation of adducts of triphenylarsine 
with mercury (II) chloride and bromide prevails over the rate of formation of the product of addition of tri- $m$-tolylarsines. This fact can be explained by the spatial factor and by electronegativity of B-substituent. It must be noted, that $\left(m-\mathrm{CH}_{3}-\right.$ $\left.\mathrm{C}_{6} \mathrm{H}_{4}\right)_{3} \mathrm{As} \cdot \mathrm{HgCl}_{2}$ is more coarse crystalline than other synthesized compounds. In aqueous solution (all the more in organic solvents) mercury (II) halides are weakly ionized and the concentration of $\mathrm{Hg}^{2+}$ ions, for example, in extracted solution of sublimate is not more than $10^{-8}$. It means that it is non-electrolyte $\left(\alpha_{\mathrm{HgCl} 2}<\alpha_{\mathrm{H} 2 \mathrm{O}}\right)$ and when $\mathrm{HgCl}_{2}$ undergoes dissociation it will stop at the first stage:

$$
\mathrm{HgCl}_{2} \leftrightarrow \mathrm{HgCl}^{+}+\mathrm{Cl}^{-}
$$

The addition of triaryl- and diarylalkyle arsines to mercury (II) halides can be considered as nucleophilic process:

$$
\mathrm{Ar}_{3} \mathrm{As}+\mathrm{HgHal}_{2} \nprec\left[\mathrm{Ar}_{3} \mathrm{As} \rightarrow \mathrm{HgHal}\right] \mathrm{Hal}
$$

The molecular electroconductivity of the obtained compounds was determined in dimethylformamide. The data of the molecular electroconductivity (less then $30 \mathrm{om}^{-1} \cdot \mathrm{cm}^{2}$ ) confirmed that these compounds are nonelectrolytes. IR spectra of the obtained compounds showed that the absorption band in the region 560$580 \mathrm{~cm}^{-1}$ (corresponding to As- $\mathrm{C}_{\mathrm{alk}}$ ), disappears, thus, the absorption band at $620 \mathrm{~cm}^{-1}$ appears which is characteristic to $A s-C_{a l k}$, when $A s$ is in $\mathrm{sp}^{3}$ hybridization state. Based on the data of molar electroconductivity and IR spectra we can propose that the compound is dimmer bridge complex:

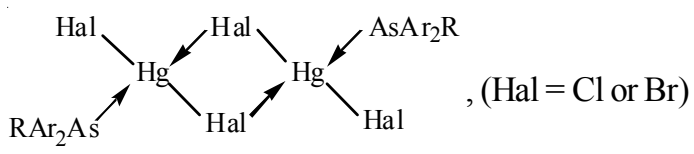

We carried out the thermographic analysis of the synthesized compounds. The thermolysis of each synthesized compounds is similar. The process of thermal decomposition can be represented according to the scheme:
We have elaborated the method of the algebraic-chemical characterization of typical structures (main characterizing structure) of synthesized compounds - $\mathrm{R}_{2} \mathrm{AsR}$, where $\mathrm{R}=m$ $\mathrm{CH}_{3} \mathrm{C}_{6} \mathrm{H}_{5} ; \mathrm{R}^{\prime}=m-\mathrm{CH}_{3} \mathrm{C}_{6} \mathrm{H}_{5} ;$ iso- $\mathrm{C}_{4} \mathrm{H}_{9} ; \mathrm{C}_{2} \mathrm{H}_{5}$. For creation of the bank of data for these chemical structures we have used the fragmentation matrix (F-matrix) method and $\lg \left(\Delta_{\mathrm{F}}\right)$ - effective topologic index for construction and investigation of fragmentation "structureproperties" type correlation equations. As the synthesized compounds are crystalline, we have constructed the correlation equation and it has the form:

$$
\begin{aligned}
& \mathrm{T}_{\text {melt }}=78 \cdot \lg \left(\Delta_{\mathrm{F}}\right)-123(\mathrm{~A}) ; \\
& \mathrm{T}_{\text {melt }}=72 \cdot \lg \left(\Delta_{\mathrm{F}}\right)-110(\mathrm{~B}),
\end{aligned}
$$

where A - for the complex of $\mathrm{HgCl}_{2}, \mathrm{~B}$ - for the complex of $\mathrm{HgBr}_{2}$.

The values of the $\mathrm{T}_{\text {melt }}$ and $\lg \left(\Delta_{\mathrm{F}}\right)$ for these compounds are presented in Table 2 .

Table 2

\begin{tabular}{|c|c|c|c|}
\hline$№$ & Coordination compounds* & $\lg \left(\Delta_{\mathrm{F}}\right)$ & $\mathrm{T}_{\text {melt }}{ }^{\circ} \mathrm{C}$ \\
\hline I & $\left(\mathrm{CH}_{3} \mathrm{C}_{6} \mathrm{H}_{4}\right)_{2} \mathrm{AsC}_{2} \mathrm{H}_{5} \cdot \mathrm{HgCl}_{2}$ & 3.35 & 137 \\
\hline $\mathrm{II}$ & $\left(\mathrm{CH}_{3} \mathrm{C}_{6} \mathrm{H}_{4}\right)_{2} \mathrm{AsC}_{4} \mathrm{H}_{9} \cdot \mathrm{HgCl}_{2}$ & 3.62 & 143 \\
\hline $\mathrm{III}$ & $\left(\mathrm{CH}_{3} \mathrm{C}_{6} \mathrm{H}_{4}\right)_{3} \mathrm{As} \cdot \mathrm{HgCl}_{2}$ & 3.81 & 173 \\
\hline IV & $\left(\mathrm{CH}_{3} \mathrm{C}_{6} \mathrm{H}_{4}\right)_{2} \mathrm{AsC}_{2} \mathrm{H}_{5} \cdot \mathrm{HgBr}_{2}$ & 3.35 & 131 \\
\hline V & $\left(\mathrm{CH}_{3} \mathrm{C}_{6} \mathrm{H}_{4}\right)_{2} \mathrm{AsC}_{4} \mathrm{H}_{9} \cdot \mathrm{HgBr}_{2}$ & 3.62 & 145 \\
\hline VI & $\left(\mathrm{CH}_{3} \mathrm{C}_{6} \mathrm{H}_{4}\right)_{3} \mathrm{As} \cdot \mathrm{HgBr}_{2}$ & 3.81 & 164 \\
\hline
\end{tabular}

* Correlation coefficient $r=0.921519$; $k=72.4423 ; b=-111.476$.

We have carried out the preliminary virtual (theoretical) bioscreening of obtained structures (using the characterizing mentioned above arsenic-containing fragments) by using internet system program PASS C\&T [27]. The estimation of probability of activity of compounds was carried out via determination of parameters $\mathrm{Pa}$ (active) and $\mathrm{Pi}$ (inactive). Based on virtual bioscreening the synthesized compounds (Table 2, I-VI), with experimentally high probability $\left(\mathrm{P}_{\mathrm{a}}=0.55-0.80\right)$, showed virtually antibacterial, antifungal,

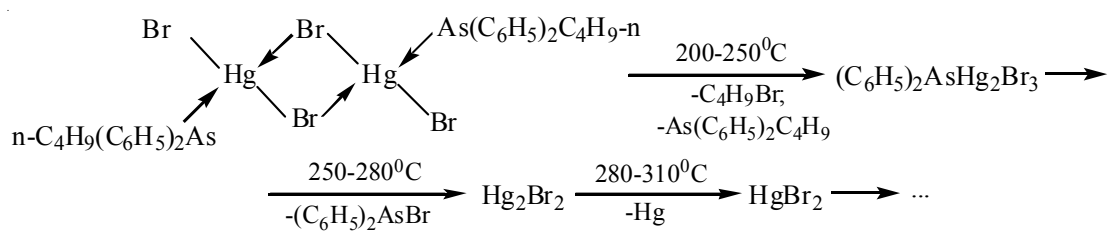


anthelmintic), antiviral and anticarcinogenic activity. Preliminary microbiologically study of the investigated compounds confirmed the virtual concepts (anticarcinogenic activity was not tested).

By using synthesized bioactive compounds (1-3-5\%) and selected polymer matrix (polyurethanes and polyester urethanes nonmodified and modified by siliconorganic oligomers) we prepared novel inorganic-organic antibiocorrosion covers. We studied tribological properties of polymer matrices and antibiocorrosion covers based on them. It was established that the friction of polyurethane and polyester urethane matrices modified by siliconorganic oligomers and antibiocorrosion covers, is higher for non-modified polyurethanes. So, the modification can be used for improvement of tribological properties of antibiocorrosive covers. By using gravimetric method the water absorption ability of obtained antibiocorrosive covers was determined. It was established that during $720 \mathrm{hrs}$ their water absorption ability was $0.01-0.03 \%$. Their testing on photochemical and thermal stability (in air, isothermal aging at $40^{\circ} \mathrm{C}$ and $60^{\circ}$ ), on action (on definite time) of "light-weather" (complex action of moisture and of air oxygen, of ultra-violet eradiation of sun or of "scattered" sunlight, $\mathrm{CO}_{2}$ ) showed, that during $1200 \mathrm{hrs}$ the initial expression, color, optical transparency and mechanical properties (homogeneity of the surface without formation of splits) of antibiocorrosive covers has not deteriorated.

\section{Coordination compounds of mercury (II) nitrate} with triaryl- and diaryl-alkylarsineoxides

One of the most important properties of oxides of tertiary arsines is a formation of coordination compounds with salts of transition metals (d-elements). It should be emphasized that this kind of compounds is well studied in case of phosphor-containing ligands. As to arseniccontaining compounds, like arenes, they are almost unstudied, if we didn't take into account several research, which have fragmentary character and are not carried out on regular basis at all, in order to make some substantial conclusion. It is noteworthy too, that complex compounds which contain arsinal group $\_\mathrm{As}-. . \mathrm{O}$ from the very beginning have become widely used in practice as the best extragents of different metals. It seems that we have to seek the cause in good capabilities of d-metals to attach oxides of tertiary arsines with formation of quite stable compounds. In all cases of extragents $\mathrm{R}_{3} \mathrm{As}=\mathrm{O}$, where $\mathrm{R}$ - organic radical, complex formation occurs according to electrondonor-acceptor interaction mechanism, at that donor function is performed by oxygen atom which is entered into arsinal group, while acceptor is represented by complex former (metal) along with its vacant (unoccupied) orbitals. As it is supposed, properties of mentioned ligands should be caused by the quality of $\mathrm{As} . . . \mathrm{O}$ bond order, which in its turn is caused by the possibility of transition of two nonbonding electrons of negatively charged substituent $(\mathrm{O})$ to the vacant 4 d-orbital of arsenic.

Taking abovementioned into account, at this time we have tried to study the complex formation ability of mercury (II) salts with oxides of triaryland diaryl-alkylarsines. If test proves its value, we will also study synthesized coordination compounds by means of accessible physical and chemical methods.

The well-known technique of triaryl(alkyl)arsine oxidation in the medium of hydrogen peroxide acetone was used in order to receive oxides of resulting tertiary arsines. Reaction runs according the following equation:

$$
\mathrm{Ar}_{3} \mathrm{As}+\mathrm{H}_{2} \mathrm{O}_{2} \rightarrow \mathrm{Ar}_{3} \mathrm{As}=\mathrm{O}+\mathrm{H}_{2} \mathrm{O}
$$

Azeotrope-former - benzol is removed from water of reaction mixture using the method of azeotropic dehydration.

The tertiary arsines are received using the action of Grignard reagent with esters of arsenic acid:

$$
(\mathrm{RO})_{3} \mathrm{As}+3 \mathrm{ArMgBr} \rightarrow \mathrm{Ar}_{3} \mathrm{As}+3 \mathrm{ROMgBr} \text {, }
$$

where $\mathrm{R}=n-\mathrm{C}_{5} \mathrm{H}_{11}$, or iso- $\mathrm{C}_{5} \mathrm{H}_{11}$, while diarylalkylarsines have been received by following method:

$$
\mathrm{Ar}_{2} \mathrm{AsCl}+\mathrm{RMgBr} \rightarrow \mathrm{Ar}_{2} \mathrm{AsR}+\mathrm{MgClBr}
$$

On the basis of many experiments it was established that possibility of mercury (II) ion 
complex formation from oxides of tertiary oxides is considerably dependent on the nature of ions entering into salt composition. Namely, most part of corresponding halogenides are either insoluble in water and spirit or slightly soluble. Among soluble salts mercury (II) acetate also have not come up to our expectations - complex compounds are formed, but goal will be achieved only after gradual drying of reaction mass that eliminates the possibility of receipt of basic product in chemically pure condition.

Thus, all our attempts to separate in individual condition the products of mercury(II) salts interaction with arsinal compounds has ended without result.

Positive results have been obtained in the experiment only in case of mercury (II) nitrate's use as original substance. Regardless of ratio between reacting substances, right from the beginning of mixtures interaction the addition products are precipitated almost in one and the same quantitative content.

It is known that oxides of tertiary arsines are monodentate ligands, while coordination number 4 is characteristic for mercury (II) ions. That's why, as far as we assured ourselves of possibility of desired product's receipt due to action of tertiary arsine oxide on mercury (II) nitrate, we have carried out basic experiments by taking into account following molar ratio:

$$
\mathrm{Hg}\left(\mathrm{NO}_{3}\right)_{2}: \mathrm{Ar}_{3} \mathrm{As}=\mathrm{O}=1: 4
$$

Reaction has been carried out in nonaqueous solutions (spirit solutions). It turns out that in all cases coordination number is equal to 4 . Formation of desired products has to be explained according to the following scheme:

$$
\mathrm{Ar}_{2} \mathrm{AsCl}+\mathrm{RMgBr} \rightarrow \mathrm{Ar}_{2} \mathrm{AsR}+\mathrm{MgClBr}
$$

Composition and structure of synthesized compounds was determined by methods of both chemical and physical-chemical analysis. Results of element analysis are given in Table 1. Formulas of obtained coordination compounds were determined via study of molar electrical conductivity of samples dissolved in dimethylformamide. As it is turns out, $\mu$ is changed within the limits of 112$123 \mathrm{Ohm}^{-1} \mathrm{~cm}^{2} \cdot$ mole $^{-1}$, that is characteristic for three-ionic electrolytes. This fact unequivocally points at the circumstance that investigated coordination compounds experience this kind of electrolytic dissociation in dimethylformamide:

$$
\begin{aligned}
& {\left[\mathrm{Hg}\left(\mathrm{O}_{-}-\mathrm{AsAr}_{3}\right)_{4}\right]\left(\mathrm{NO}_{3}\right)_{2} \rightarrow } \\
\rightarrow & {\left[\mathrm{Hg}\left(\mathrm{O}_{\ldots}-\mathrm{AsAr}_{3}\right)_{4}\right]_{2}++2 \mathrm{NO}_{3}-}
\end{aligned}
$$

As to coordination rule of ligands, with the purpose of solution of this problem we have studied the IR spectra of synthesized compounds. Their analysis shows that, as it was expected, a ligand is coordinated with mercury (II) ion via oxygen atom of arsinal group. For instance, intensive absorption band in $880-900 \mathrm{~cm}^{-1}$ area, which is referred to valence vibrations $\left(\mathrm{V}_{\mathrm{As}=\mathrm{O}}\right)$ of As $-\mathrm{O}$ bond is manifested on all spectrograms of initial oxides of tertiary arsines. Presence of phenyl groups in the composition of synthesized compounds is confirmed by existence of absorption bands in 1590, 1490, 1440, 1170, 1156, $1080,1030,1000,745,690 \mathrm{~cm}^{-1}$ areas. As- $\mathrm{C}_{\mathrm{alk}}$ bond is confirmed by existence of absorption bands in $475 \mathrm{~cm}^{-1}$ area. It should be noted that all abovementioned bands, except of arsinal group is basically kept in spectra of interaction of oxides of tertiary arsines and mercury (II) nitrate. It is not surprising, since namely by means of oxygen atom of arsinal group a ligand bounds with complex former. In particular, frequency of valence vibrations of $\mathrm{As}-\mathrm{O}$ bonds in resulting complexes' spectra is decreased by $20-50 \mathrm{~cm}^{-1}$. This fact, in its turn, points at the circumstance that ligands are monodentate.

While considering absorption IR spectra we make sure that in $\left[\mathrm{Hg}\left(\mathrm{O}=\mathrm{AsAr}_{3}\right)_{4}\right]\left(\mathrm{NO}_{3}\right)_{2}$ and $\left[\mathrm{Hg}\left(\mathrm{O}=\mathrm{As}\left(\mathrm{ROAr}_{2}\right)_{4}\right]\left(\mathrm{NO}_{3}\right)_{2}\right.$ compounds a nitrate-ion $\left(\mathrm{NO}_{3}\right)^{-}$is located in second sphere of complex, that is determined by means of IR spectral data and points at the splitting of absorption band in 1300-1500 $\mathrm{cm}^{-1}$ area, while $\mathrm{V}_{\text {(NO3) }}$ absorption band in $840 \mathrm{~cm}^{-1}$ is singlet. The fact that bond between complex former and ligand is strengthened by means of oxygen atom of arsinal of arsenic-containing compounds is confirmed by availability of absorption band in $\sim 930 \mathrm{~cm}^{-1}$ area of IR spectra.

All above mentioned gives us an opportunity to make an univocal conclusion that synthesized coordination compounds represent three-ionic complexes that, along with molar electric conductivity is confirmed by spectral analysis of researched substances. 
Behaviour of synthesized compounds during heating was also studied. Tetra(di-m-tolylbuthylarsinoxymercury (II) nitrate thermograph is given by us as a sample. As it turns out the thermolysis occurs quite difficult and contains no more than 5 exothermal effects and 4 endothermic effects. Using detailed analysis we make sure that exothermal effect indicated at the DTA, as a rule is not in compliance with weight gain. Therefore, the mentioned effect cannot be caused by addition reaction, for example, by involvement of air oxygen in chemical reaction. We guess that in this case we deal with even more complicated transformations that, maybe, should be caused by intramolecular regrouping into thermodynamically advantageous condition. This fact in our opinion can be explained by retro-Arbuzov regrouping in ligand molecule subsequent to which takes place complex melting during compound's heating up to high temperature.

It is not impossible that diphenyl ester of arsenic acid would be received by further oxidation of $\mathrm{Ar}_{2}$ AsOR-type compound, but in this case the role of oxidizing agent may be played not by air oxygen but nitrate-ion oxygen according to the general pattern:

$$
\mathrm{Ar}_{3} \mathrm{As}+\mathrm{H}_{2} \mathrm{O}_{2} \rightarrow \mathrm{Ar}_{3} \mathrm{As}=\mathrm{O}+\mathrm{H}_{2} \mathrm{O}
$$

As it was mentioned above, we have an opportunity to make such conclusion due to the fact that weight gain doesn't occur, though there is a pronounced exo-effect at DTA curve. Besides, it is well known from literature that such transformations are quite allowable and are caused by system's transition to so-called energetically "advantageous condition".

Taking into account this consideration we can represent the thermolysis of tetra(di- $m$-tolyl$n$-buthylarsinoxide) mercury (II) nitrate as follows: sample decomposition begins at $90{ }^{\circ} \mathrm{C}$ and gradually continues up to $600^{\circ} \mathrm{C}$. Weight loss in the range of $90-445{ }^{\circ} \mathrm{C}$ is $21,66 \%$ that corresponds with break-away (theoretical 23,70\%) of $\mathrm{N}_{2} \mathrm{O}_{3}$ and tertiary arsines $\left(m-\mathrm{CH}_{3} \mathrm{C}_{6} \mathrm{H}_{4}\right)_{2} \mathrm{AsC}_{4} \mathrm{H}_{9}$ from the sample. In the same range, especially from
$220{ }^{\circ} \mathrm{C}$ takes place intensive "intramolecular transformations" that, as we mentioned, have to be explained by retro-Arbuzov regrouping. Under 465-600 ${ }^{\circ} \mathrm{C}$ conditions takes place separation of organic fragment. At that, mercury (II) oxide also experiences final decomposition that is succeeded by complete "vaporization" of residue. Thus, at the last stage not only ligand's removal occurs, but also decomposition and vaporization of inorganic residue itself: $\mathrm{HgO} \rightarrow \mathrm{Hg}+1 / 2 \mathrm{O}_{2}$, which is one of the basic distinctive features of mercury (II) complex compounds in contra-distinction from similar compounds of all other d-elements.

Hence, taking into account above mentioned, the most likely pattern of thermolysis of considered complex compound can be represented as follows below the page.

Thus, as a result of our research it was established that products of interaction of mercury (II) nitrate and oxides of tertiary arsines are corresponding complex compounds.

Composition and structure of synthesized substances were determined using methods of IR spectroscopy, element analysis and molar electric conductivity (Table 3). It is shown that bond between complex former and ligand is strengthened by means of oxygen atoms of arsinal group. Nitrate-ion is located at the second sphere of complex.

\section{General results}

\section{IR spectroscopic study:}

In the the IR spectrum of $\left[\left(\mathrm{Ph}_{3} \mathrm{AsCH}_{2} \mathrm{I}\right] \mathrm{I}_{3}\right.$ the aromatic $\mathrm{C}-\mathrm{H}$ stretching bands appear in the $3047 \mathrm{~cm}^{-1}$ and the aliphatic $\mathrm{C}-\mathrm{H}-$ in the 2877 (asym.) and 2946 (sym.) $\mathrm{cm}^{-1}$ regions. Skeletal vibrations, representing aromatic $\mathrm{C}=\mathrm{C}$ absorb in the $1581-1434 \mathrm{~cm}^{-1}$ range. The $\mathrm{C}-\mathrm{H}_{\mathrm{ar}}$ bending bands appear in the regions $1241-1025 \mathrm{~cm}^{-1}$ (in plane bending) and 833-686 $\mathrm{cm}^{-1}$ (out-of plane bending). The week and medium stretching bands appear at the $462-481 \mathrm{~cm}^{-1}\left(\mathrm{As}-\mathrm{C}_{\mathrm{ar}}\right)$ and $685 \mathrm{~cm}^{-1}\left(\right.$ As- $\mathrm{C}_{\text {aliph }}$ ), characterized for $\mathrm{As}-\mathrm{C}_{4}$ bonds in tetrahedral position.

\section{X-ray Study:}

The structures of cation and anion of the obtained complexes are shown in Fig. 7.

$$
\begin{aligned}
& {\left[\mathrm{Hg}\left(\mathrm{O}=\mathrm{As}\left(\mathrm{C}_{6} \mathrm{H}_{4}-\mathrm{CH}_{3}-\mathrm{m}\right)_{2} \mathrm{C}_{4} \mathrm{H}_{9}-\mathrm{n}\right)_{4}\right]\left(\mathrm{NO}_{3}\right)_{2} \quad-\mathrm{N}_{2} \mathrm{O}_{3} ;\left(\mathrm{m}_{-}-\mathrm{CH}_{3} \mathrm{C}_{6} \mathrm{H}_{4}\right)_{2} \mathrm{AsC}_{4} \mathrm{H}_{9}-\mathrm{n}} \\
& 465-600{ }^{\circ} \mathrm{C} \\
& \mathrm{HgO}\left(\mathrm{m}-\mathrm{CH}_{3} \mathrm{C}_{6} \mathrm{H}_{4} \mathrm{As}-\mathrm{OC}_{4} \mathrm{H}_{9} \mathrm{CH}_{3}-\mathrm{m}\right)_{3} \rightarrow \mathrm{Hg}+3\left(\mathrm{~m}-\mathrm{CH}_{3} \mathrm{C}_{6} \mathrm{H}_{4} \mathrm{O}\right)_{2} \mathrm{AsOC}_{4} \mathrm{H}_{9}-\mathrm{n}
\end{aligned}
$$


Some physical constants and data of element analysis of $\left[\mathrm{Hg}\left(\mathrm{OAs}(\mathrm{R}) \mathrm{Ar}_{2}\right)_{4}\right]\left(\mathrm{NO}_{3}\right)_{2}$

\begin{tabular}{|c|c|c|c|c|c|c|c|c|c|}
\hline \multirow[t]{2}{*}{ № } & \multirow[t]{2}{*}{$\mathrm{Ar}$} & \multirow[t]{2}{*}{$\mathrm{R}$} & \multirow{2}{*}{$\begin{array}{l}\text { Melting } \\
\text { Point, } \\
\text { t, }{ }^{\circ} \mathrm{C}\end{array}$} & \multirow{2}{*}{$\begin{array}{l}\text { Molar electro- } \\
\text { conductivity in } \\
\text { dimethyl-form- } \\
\text { amide at } 25^{\circ} \mathrm{C} \\
\text { omi }^{-1} \mathrm{sm}^{2} \text { moli }^{-1}\end{array}$} & \multicolumn{2}{|c|}{ Found, \% } & \multirow[b]{2}{*}{ Brutto formula } & \multicolumn{2}{|c|}{ Calculated, $\%$} \\
\hline & & & & & As & $\mathrm{Hlg}$ & & As & Hlg \\
\hline 1 & $m-\mathrm{CH}_{3} \mathrm{C}_{6} \mathrm{H}_{4}$ & $n-\mathrm{C}_{4} \mathrm{H}_{9}$ & $95-96$ & 112.5 & 18.05 & 12.20 & $\mathrm{C}_{72} \mathrm{H}_{92} \mathrm{As}_{4} \mathrm{HgN}_{2} \mathrm{O}_{10}$ & 18.23 & 12.21 \\
\hline 2 & $m-\mathrm{CH}_{3} \mathrm{C}_{6} \mathrm{H}_{4}$ & iso- $\mathrm{C}_{3} \mathrm{H}_{7}$ & $121-122$ & 114.7 & 18.66 & 12.65 & $\mathrm{C}_{68} \mathrm{H}_{84} \mathrm{As}_{4} \mathrm{HgN}_{2} \mathrm{O}_{10}$ & 18.87 & 12.64 \\
\hline 3 & $p-\mathrm{CH}_{3} \mathrm{C}_{6} \mathrm{H}_{4}$ & $n-\mathrm{C}_{4} \mathrm{H}_{9}$ & $87-88$ & 118.5 & 18.11 & 12.18 & $\mathrm{C}_{72} \mathrm{H}_{92} \mathrm{As}_{4} \mathrm{HgN}_{2} \mathrm{O}_{10}$ & 18.23 & 12.21 \\
\hline 4 & $p-\mathrm{CH}_{3} \mathrm{C}_{6} \mathrm{H}_{4}$ & iso- $\mathrm{C}_{4} \mathrm{H}_{9}$ & $118-119$ & 116.9 & 18.14 & 12.18 & $\mathrm{C}_{72} \mathrm{H}_{92} \mathrm{As}_{4} \mathrm{HgN}_{2} \mathrm{O}_{10}$ & 18.23 & 12.21 \\
\hline 5 & $\mathrm{C}_{6} \mathrm{H}_{5}$ & $\mathrm{C}_{6} \mathrm{H}_{5}$ & $128-129$ & 120.4 & 18.41 & 12.44 & $\mathrm{C}_{72} \mathrm{H}_{60} \mathrm{As}_{4} \mathrm{HgN}_{2} \mathrm{O}_{10}$ & 18.59 & 12.46 \\
\hline 6 & $m-\mathrm{CH}_{3} \mathrm{C}_{6} \mathrm{H}_{4}$ & $\mathrm{C}_{2} \mathrm{H}_{5}$ & 108-109 & 122.6 & 19.23 & 13.14 & $\mathrm{C}_{64} \mathrm{H}_{71} \mathrm{As}_{4} \mathrm{HgN}_{2} \mathrm{O}_{10}$ & 19.56 & 13.11 \\
\hline
\end{tabular}
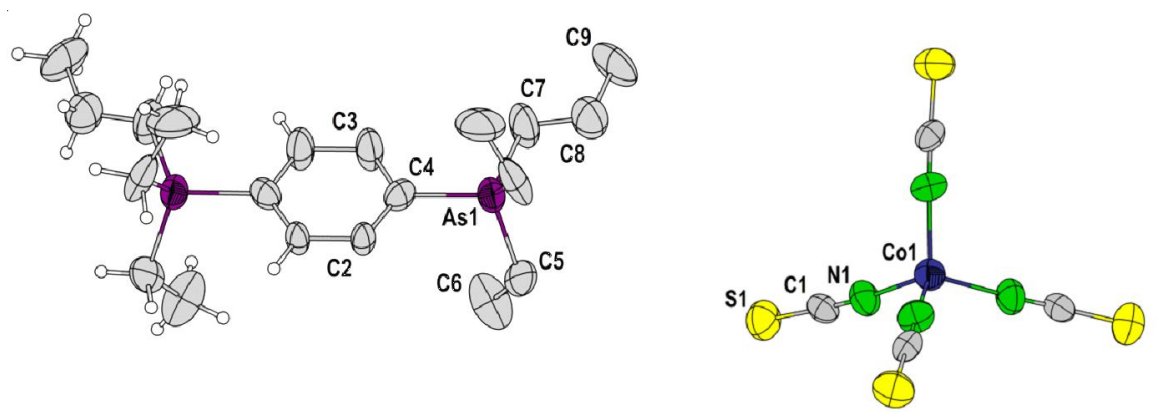

Fig. 7. Structures of ${ }^{+}\left[\left(\mathrm{i}_{-} \mathrm{C}_{3} \mathrm{H}_{7}\right)\left(\mathrm{C}_{2} \mathrm{H}_{5}\right)_{2} \mathrm{As}\left(\mathrm{C}_{6} \mathrm{H}_{5}\right) \mathrm{As}\left(\mathrm{C}_{2} \mathrm{H}_{5}\right)_{2}\left(\mathrm{i}-\mathrm{C}_{3} \mathrm{H}_{7}\right)\right]^{+}$cation and $\left[\mathrm{Co}(\mathrm{NCS})_{4}\right]^{2-}$ anion

Compound crystallises in the monoclinic, space group $\mathrm{P} 2 / \mathrm{n}$ (No. 14) with $a=10.197$ (1) $\AA$, $b=13.152(1) \AA, c=16.882(1) \AA, \beta=93.01(1)^{\circ}$ and four formula units per unit cell. The crystal structure was solved via the Patterson method. For refinement full-matrix least-squares methods were applied.

Despite the identification of various arsonium cations, few examples have been comprehensively studied and rarely mentioned in the literature [2; 23; 31]. The well known and studied cation is tetra-phenyl-arsonium, in which four indipendent arsenic atoms with As- $\mathrm{C}$ distances in the range 1.910-1.921 and angles at arsenic between 106.1 and 110.7 assigned to the tetrahedral geometry. Tetrahedral configuration is also observed in arsonium cations carrying benzyl, methyl, 4-methyl-phenyl and naphthalen-1-yl groups with As-C bond lengths 1.889-1.949 and C-As-C angles 106.9-112.5. A variety of complexes has been isolated with structures based on a hydrogen bonded $\left.\left(\mathrm{Ph}_{3} \mathrm{AsO}\right)_{2} \mathrm{H}\right]^{+}$cation with $\mathrm{I}_{3}, \mathrm{BF}_{4}$ and $\mathrm{AlCl}_{4}$ counterions. The cation-anion contacts (3.363 and $3.58 \AA$ ) in 1,3-dimethyldiaza-2arsenanium tetrachlorogallate are within the sum of the Van der Waal's radii for As and $\mathrm{Cl}$ (As, $2.0 \AA ; \mathrm{Cl}, 1.7 \AA$ ). Recently we have isolated $\left[\mathrm{R}_{3} \mathrm{AsCH}_{2} \mathrm{I}\right]\left[\mathrm{I}_{3}\right]$ (a) and $\left[\mathrm{R}_{2}\left(\mathrm{R}^{\prime}\right) \mathrm{AsCH}_{2} \mathrm{I}\right]\left[\mathrm{I}_{3}\right]$ (b)
$\left(\mathrm{R}=\mathrm{Pr}, \mathrm{Pr}, \mathrm{Bu}, \mathrm{iBu}, \mathrm{Ph}, \mathrm{am} ; \mathrm{R}^{\prime}=\mathrm{Bu}, \mathrm{Ph}\right)$ arsonium compounds in $\mathrm{As}-\mathrm{C}$ interatomic distances range in the 1.906-1.924 $\AA$ and C-As-C angles of the cation - $105.3-109.8^{\circ}$ (a) as well as the As-C interatomic distances range in the 1.921-1.953 $\AA$ and C-As-C angles of the cation - 106.8-114.7 ${ }^{\circ}$ (b). The As-C bond lengths of Ph-substituted compound are shorter than izo-Bu-substituted compound. The anion has symmetric linear structure: $\left[\mathrm{I}_{2.91}-\mathrm{I}_{2.91-} \mathrm{I}\right]^{-}$, as it is in $\left[\mathrm{As}\left(\mathrm{C}_{6} \mathrm{H}_{5}\right)_{4}\right]^{+}$ $\left[\mathrm{I}_{2.90}{ }^{-\mathrm{I}}-2.90^{-\mathrm{I}}\right]^{-}$.

For some transition complexes containing ortho-phenylenebis(dimethylarsine) and its phenyl analogues, as chelates, the octahedral arrangement dominates - $\left[\mathrm{Rh}(\text { diars })_{2} \mathrm{Cl}\left(\mathrm{CO}_{2}\right)\right]$ has an octahedral geometry, containing a molecule of carbon dioxide coordinated via carbon atom, as well as cobalt complex $\left.[\mathrm{Co} \text { (diars) })_{3}\right]\left[\mathrm{BF}_{4}\right]_{3} 2 \mathrm{H}_{2} \mathrm{O}$, with As-Co distances ranging between 2.365 and $2.395 \AA$ and the platinum complex $\left[\mathrm{Pt}(\text { diars })_{2} \mathrm{I}_{2}\right]\left[\mathrm{BF}_{4}\right]_{2}$, which has trans-octahedral geometry (As-Pt $2.45 \AA$ ).

The arsenic-carbon bond lengths and angles of the synthesized bisarsonium tetra-izothiocyanato-cobaltate (II) complex are corresponding to the tetrahedral configuration, therefore, the As-c bond legths range in the 1.911-1.959 $\AA$ and angles- 107.4-110.2 ${ }^{\circ}$; as wel 


\section{ТЕХНИКО-ТЕХНОЛОГИЧЕСКИЕ ИННОВАЦИИ}

as, in the counterion, Co-N bond lengths are equal $1.964 \AA$ and angles $105.4^{\circ}$, respectively. The crystal packing is due to the cation-anion contacts and week intra-or intermolecular interaction forces.

In the given research we provided the structures of ${ }^{+}\left[\left(\mathrm{i}-\mathrm{C}_{3} \mathrm{H}_{7}\right)\left(\mathrm{C}_{2} \mathrm{H}_{5}\right)_{2} \mathrm{As}\left(\mathrm{C}_{6} \mathrm{H}_{5}\right)\right.$ $\left.\mathrm{As}\left(\mathrm{C}_{2} \mathrm{H}_{5}\right)_{2}\left(\mathrm{i}-\mathrm{C}_{3} \mathrm{H}_{7}\right)\right]^{+}$cation and $\left[\mathrm{Co}(\mathrm{NCS})_{4}\right]^{2-}$ anion and crystal packing of $\left[(\mathrm{i}-\mathrm{Pr})(\mathrm{Et})_{2}\right.$ $\left.\mathrm{As}(\mathrm{Ph}) \mathrm{As}(\mathrm{Et})_{2}(\mathrm{i}-\mathrm{Pr})\right]\left[\mathrm{Co}(\mathrm{NCS})_{4}\right]$.

The preliminary research showed that the synthesized compounds have bactericide properties. They may be used against some phyto-pathogenic microorganisms. Synthesized arsenic-manganese complexes, dropped into the several functional polymer matrixes, may serve as a basis to prepare new bioactive materials with regular duration of the action: antibiocorrosion coatings for multifunctional purpose foamed polyurethane materials and various dipping compounds.

\section{REFERENCES}

1. Akhmetov N.S. General and Inorganic Chemistry. Moscow, HS Publ., 2004. (In Russian).

2. Baláž P., Sedlák J. Arsenic in Cancer Treatment: Challenges for Application of Realgar Nanoparticles (A Minireview). Toxins, 2010, no. 2, pp. 1568-1581.

3. Barbakadze Kh., Brostow W., Gakhutishvili M., Gigauri R., Gventsadze D., Lekishvili N., LobzhanidzeT. Inorganic-Organic Hybrid Materials from Low-Cost Industrial Waste and Secondary Resources. POLYCHAR 17 - World Forum on Advanced Materials. April 20-24, 2009. Rouen, 2009.

4. Brostow W., Gakhutishvili M., Gigauri R., Halay E.Y.L., Japaridze Sh., Lekishvili N. A New Possibility of Separation of Natural Oxide Forms of Arsenic and Antimony. Chem. Eng. J. (USA), 2010, no. 159 , pp. $24-26$.

5. Chelidze I. Study of the Reactions of the Obtaining of Arsenic Sulfides. PhD Dissertation. Moscow, 1975.

6. Gakhutishvili M., Gigauri R., Vachnadze E., Chikovani O. Arsenic Eduction from RealgarAuripigment Ores of Racha (Georgia). Georgian Eng. News, 2000, no. 2, p. 174.

7. Gakhutishvili M. Arsenic Utilizing Production Waste: A Foundation for Development of Science and Society. Intelecti, 2000, no. 17, pp. 23-24.

8. Gakhutishvili M., Gigauri R., Machaidze Z., Koranashvili G., Kokhreidze M. Synthesis and
Properties of Amine Complexes of Dithio-Arsenates. Bull. Georgian Acad. Sci., 2001, no. 164, p. 33.

9. Gigauri N., Pareshishvili N., Gigauri R. Chemical Study of the Arsenic-Containing Production Waste of Racha Mining Plant. Georgian Chemical Journal, 2006, no. 6, pp. 599-604.

10. Gigauri R., Gakhutishvili M., Giorgadze K., Machaidze Z. A Method of Sodium Dithioarsenate (V) Production from Hydrometaiiurgical Industrial Wastes of Non-Ferrous and Noble Metals. Proc. Georgian Acad. Sci., 2004, no. 30, p. 205.

11. Gigauri R. Arsenic and the Environment. Tbilisi University Publishers, 2004, pp. 15-22.

12. Gigauri R., Chachava G., Gverdtsiteli M., Laperashvili I. Extract of the Arsenic from Industrial Waste. Proceeding of the Academy of Sciences of Georgia. Sieria of Chemistry, 2007, no. 33 (4), p. 395.

13. Gigauri R., et al. Investigation of ArsenicContaned Industrial Wsate of Mining Factory in Racha (Georgia). Georgian Chemical Journal, 2006, no. 6 (6), pp. 599-604.

14. Gigauri R. Synthesis and Transformation of the Arsenic Organic Compounds Based on $\mathrm{As}_{4} \mathrm{O}_{6}$. Dr. Techn. Sci. Diss. Tbilisi, 1987.

15. Gigauri R.D., Pareshishvili N.G., Gigauri R.J. New Possibilities of Processing Pyro-Metalurgical Wastes of Production of Non-Ferous and Noble Metals: Production of Arsenic (III) Oxide From the Waste. Georgian Engineering News, 2006, no. 1, pp. 232-237.

16. Gigauri R., Chelidze I., Gakhutishvili M., Chirakadze A. Bacterical-Chemical Extraction of the Arsenic from Arsenic Industrial Waste and the Thechnology of the Obtaining of Superclean Arsenic. Nanochemistry and Nanotechnology, 2011, pp. 183-187.

17. Gigauri R., Gigauri N., Lekishvili N. Obtaining the "White Arsenic" from Arsenic Industrial Waste. International Conference "Compounds and Materials with Specific Properties Based on Industrial Waste, Secondary and Natural Recourses". Book of Abstracts. Tbilisi, 15-16 July, 2010, p.13.

18. Grund S.C., Kanusch K., Wolf H.U. Arsenic and Arsenic Compounds. UII-mens Encyclopedia of Industrial Chemistry. VCH-Wiley, Weinheim, 2006.

19. Hazziza-Laskar J.and Helary G, Sauvet G. Biocidal Polymers Active by Contact. IV. Polyurethanes Based on Polysiloxanes with Pendant Primary Alcohols and Quaternary Ammonium Groups. Journal of Applied Polymer Science, 1995, vol. 1, no. 58 , pp. 77-84.

20. Isakov V., Nesterov V. Color Metalurgy, 1962, vol. 5, pp. 72-103.

21. Jokai J., Hegoszki P.F. Stability and Optimization of Exstractrion of four Arsenic Species. Microchemical Journal, 1998, vol. 59, no. 1. 


\section{ТЕХНИКО-ТЕХНОЛОГИЧЕСКИЕ ИННОВАЦИИ}

22. Kasradze Kh., Bezarashvili G., Lekishvili N., Rusia M., Pichkhaia B. Synthesis, Use and Study of Kinetics of Triisoamyl-Arsenate Obtained by Etherification Orthoarsenic Acid with Isoamyl Alcohol. Georgian International Journal in Science \& Technology. New York, Nova Sci. Publ., 2008, vol. 1, no. 1, pp. 63-69.

23. Khidasheli A. Oxidation of Arsenic row Sulfide Forms. PhD Diss. Tbilisi, 1996.

24. Kundu S., Kumar G.S., Madhuri M., Tarasankar P. Micelle Bound Redox Dye Marker for Nanogram Level Arsenic Detection Promoted by Nanoparticles. NewJ. Chem., 2002, vol. 26, pp. 1081-1084.

25. Lekishvili N., Arabuli L., Beruashvili T., Lobzhanidze T., Barbakadze Kh., Kezherashvili M. Antibiocorrosive Covers Based on some Arsenic Compound Derivatives. $1^{\text {st }}$ International Caucasian Symposium on Polymers \& Advanced Materials. 11 14 Sept. Tbilisi, pp. 74-75.

26. Lekishvili N., Brostow W., Gigauri R., Rusia M., Lobzhanidze T., Arabuli L., Gakhutishvili M., Kezherashvili M., Barbakadze Kh., Gigauri N. Rational and Effective Use of Georgian Region Arsenic Industrial Waste for Obtaining Compounds and Materials with Specific Properties. Proceedings of the First Online International Conference on "The Real Environmental Crisis - Effects in Tourism Development, Conflicts and Sustainability". Romania, Kraiova, 30 November, 2011, pp. 25-59.

27. Lekishvili N., Rusia M., Pichkhaia B., Gakhutishvili M., Arabuli L., Barbakadze Kh. Creation of Bioactive Arsenic and Antimony Compounds from
Arsenic Processing Industrial Waste and Materials with Predefined Properties. International Conference on Materials and their Recycling, September 17-19, 2008, Tbilisi.

28. Lobzhanidze T., Gigauri R. Synthesis and some Properties of Tetrabromocadmiates (II) of iodmethylen-trialkyl-(aryl)arsenates. Bulletin of the Academy of Sciences of Georgia, 2003, vol. 2, no. 168, pp. 265-268.

29. Morin G., Calas G. Arsenic in Soils, Mine Tailings, and Former Industrial Sites. Elements, vol. 2.

30. Nasibulina S.S. Razvitie issledovaniy $v$ oblasti khimii mishiakoorganicheshikh soedineniy. Dis. kand. khim. nauk. Moscow, 1978. 190 p. (in Russian).

31. Rahman C.S., Yanful E.K. Arsenic and Chromium Removal by Mixed Magnetite-Maghemite Nanoparticles and the Effect of Phosphate on Removal. Journal of Environmental Management, 2010, vol. 91, pp. 2238-2247.

32. Sakhvadze L., Adamia T., Buachidze Z., Gvakharia V., Chirakadze A. Bacterial Leaching of Arsenic from Arsenic ore Waste and Industrial Production of Arsenic Compounds. Proceedings of Microbiology Institute of the Azerbaijan National Academy of Sciences, 2009.

33. Tomas H. Patent USA, 2976382.

34. Tskhakaia N.Sh. Prospects on Production of Arsenic and Its Compounds. Proceedings of the AllUnion Conference "The Prospects of Production of Arsenic and Its Compounds including the Ultra-Pure Ones". Tbilisi, 1978, pp. 3-18.

\section{ИННОВАЦИОННОЕ ПРИМЕНЕНИЕ НЕКОТОРЫХ КООРДИНАЦИОННЫХ СОЕДИНЕНИЙ МЫШЬЯКА И СУРЬМЫ}

\section{Нодар Лекишвили}

Доктор химических наук, профессор, факультет точных и естественных наук, Тбилисский государственный университет им. Иванэ Джавахишвили nodar@lekishvili.info просп. И. Чавчавадзе, 3, 0179 Тбилиси, Республика Грузия

\section{Майя Русиа}

Научный сотрудник,

Институт неоргано-органических гибридных соединений и нетрадиционных материалов, Тбилисский государственный университет им. Иванэ Джавахишвили nodar@1ekishvili.info просп. И. Чавчавадзе, 3, 0179 Тбилиси, Республика Грузия 


\section{Лили Арабули}

Научный сотрудник,

факультет точных и естественных наук,

Тбилисский государственный университет им. Иванэ Джавахишвили

nodar@1ekishvili.info

просп. И. Чавчавадзе, 3, 0179 Тбилиси, Республика Грузия

\section{Хатуна Барбакадзе}

Научный сотрудник

факультет точных и естественных наук,

Тбилисский государственный университет им. Иванэ Джавахишвили

nodar@1ekishvili.info

просп. И. Чавчавадзе, 3, 0179 Тбилиси, Республика Грузия

\section{Иванэ Дидбаридзе}

Научный сотрудник,

Государственный университет Акакия Церетели

atsu@atsu.edu.ge

ул. Тамары Мефе, 59, 4600 г. Кутаиси, Республика Грузия

\section{Мадона Самхарадзе}

Научный сотрудник,

Государственный университет Акакия Церетели

atsu@atsu.edu.ge

ул. Тамары Мефе, 59, 4600 г. Кутаиси, Республика Грузия

\section{Гиорги Джошвили}

Научный сотрудник

факультет точных и естественных наук,

Тбилисский государственный университет им. Иванэ Джавахишвили nodar@1ekishvili.info

просп. И. Чавчавадзе, 3, 0179 Тбилиси, Республика Грузия

Аннотация. На основе соединений мышьяка, полученных путем преобразования мышьяка промышленных отходов и природных ресурсов (мышьяк (III), оксид мышьяка (III), хлориды, алкоксиды, оксид сурьмы (III)), нами были получены и изучены новые комплексные соединения: «белый мышьяк», сверхчистый металлический мышьяк и различные материалы с особыми свойствами. Показана перспектива для изготовления на основе промышленных отходов и природных ресурсов полупроводников, оптического стекловолокна и биомедицинских нанокомпозитов.

Ключевые слова: мышьяк, сурьма, химические соединения, координации, неорганические-органические комплексы, биомедицинские нанотехнологии. 